\title{
PENGARUH KUALITAS PELAYANAN DAN KUALITAS PRODUK TERHADAP KEPUASAN KONSUMEN PADA USAHA MANDIRI (JAMU KELILING) MILIK IBU SUMARMI TEGALROTAN CIPUTAT TANGERANG SELATAN
}

\author{
${ }^{1 *}$ Ali Maddinsyah, ${ }^{2}$ Muntamah Janah \\ Universitas Pamulang, Tangerang Selatan, Banten, Indonesia \\ *alimaddinsyah@unpam.ac.id
}

\begin{abstract}
Abstrak
Penelitian ini bertujuan untuk mengetahui pengaruh kualitas pelayanan dan kualitas produk baik secara parsial maupun secara bersama-sama terhadap Kepuasan Konsumen pada Usaha Mandiri (Jamu Keliling) Milik Ibu Sumarmi Tegalrotan Ciputat Tangerang Selatan. Metode penelitian ini menggunakan metode kuantitatif dengan sifat deskriptif dan asosiatif. Tehnik pengambilan sampel dalam penelitian ini menggunakan tehnik Accidental sampling dengan jumlah sampel sebanyak 100 responden. Pengujian data kuesioner dianalisis dengan menggunakan perhitungan SPSS versi 26, pada uji regresi linear sederhana dan berganda, uji koefesien korelasi, koefesien determinasi dan uji hipotesis. Bardasarkan hasil penelitian bahwa kualitas pelayanan terbukti berpengaruh terhadap kepuasan konsumen, hal ini dibuktikan dengan nilai thitung $>\operatorname{ttabel}(7,746>1,984)$ dan nilai signifikansi sebesar $0,000<0,05$, bahwa kualitas produk berpengaruh terhadap kepuasan konsumen hal ini dibuktikan dengan nilai thitung $>$ ttabel $(9,391>1,984)$ dan nilai signifikansi sebesar $0,000<0,05$, terakhir bahwa kualitas pelayanan dan kualitas produk secara bersama-sama (simulitan) berpengaruh terhadap kualitas konsumen, hal ini dibuktikan dengan nilai Fhitung $>$ Ftabel $(46,273>3,090)$ nilai signifikansi $0,000<0,05$. Dengan dapat disimpulkan bahwa kualitas pelayanan dan kualitas produk baik secara parsial maupun simultan berpengaruh positif dan signifikansi terhadap kepuasan konsumen.
\end{abstract}

Kata Kunci: Kualitas Pelayanan, Kualitas Produk dan Kepuasan Konsumen

\section{Abstract}

This research is aim to findout the influence of service quality and product in partially or together towards customer satisfaction to independent business (Jamu Keliling) owned by Mrs. Sumarmi Tegalrotan Ciputat Tangerang Selatan. This research uses quantitative methods with descriptive and associative properties. The sampling technique with a sample size of 100 respondents test at questioner data was analized using the spss version 26 calculation, on a simple multiple linear regression test, correlation coefficient test, coefficient determination and hypothesis testing base on the result that the service quality proven to have an effect on consumer satisfaction. This is proved by the table count value $(7,746>1,984)$ and a significant value of $0,000<$ 0,05 , that the product quality proven to have an effect on consumer satisfaction this is proved by the table count of $(9,391>1,984)$ and a significant value at $0,000<0,05$, finally product quality and service quality go hand in hand (simultaneously) effect the quality of consumers. This is proved by the table count value of $(46,273>3,090)$ and a significant value of $0,000<0,05$ white this it can be concluded that product quality and service quality, either partially or simultaneously have a positive and significant impact on consumer satisfaction.

Key Words: Service Quality, Product Quality And Consumer Satisfaction

\section{PENDAHULUAN}

Jamu merupakan minuman berkhasiat dari Indonesia sebagai minuman kesehatan, mencegah, dan menyembuhkan berbagai penyakit. Jamu disajikan dengan berbagai jenis, mengingat di Indonesia memiliki tanaman herbal berjumlah cukup banyak. Setiap daerah mempunyai jenis ciri khas jamu yang berbeda, menyesuaikan dengan tanaman herbal yang tumbuh didaerahnya. Mengolah umumnya jamu tidak terlalu rumit, kebanyakan hanya mengambil sari dari perasan tumbuhan herbal tetapi prosesnya cukup memakan waktu lebih dari 3 jam. Biasanya sari diperoleh dengan 
cara ditumbuk. Jamu umumnya berbahan dasar kunyit, temulawak, lengkuas, jahe, kencur, dan kayu manis. Khusus gula jawa, gula batu, dan jeruk nipis biasanya digunakan sebagai penambah rasa segar dan rasa manis. Uniknya, dalam pembuatan jamu juga disesuaikan takaran tiap bahan, suhu, lama menumbuk atau merebus, dan lainnya. Jika tidak diperhatikan dengan baik, akan kehilangan khasiat dari bahan-bahannya bahkan bisa membahayakan tubuh. Begitu juga dengan perkembangannya, tradisi minum jamu mengalami pasang surut sesuai zamannya. Secara garis besar terbagi dari zaman pra-sejarah saat pengolahan hasil hutan marak berkembang, zaman penjajahan Jepang, zaman awal kemerdekaan Indonesia, hingga saat ini. Masyarakat Indonesia sejak zaman Kerajaan Mataram hingga kini masih menggunakan jamu. Minuman khas Indonesia ini telah menjadi kebanggaan tersendiri.

Pelaku industri jamu ini tersebar diseluruh wilayah Indonesia termasuk pada kota-kota besar seperti kota Tangerang. Jumlah penduduk Tangerang Selatan di tahun 2019 berjumlah 1.747.906 jiwa. Dengan jumlah penduduk yang banyak tersebut tentunya, setiap warganya memiliki profesi yang berbeda-beda. Salah satu profesi yang dengan mudah kita temui adalah tukang jamu gendong/keliling. Banyaknya pesaing pada bisnis jamu gendong/keliling membuat setiap pelaku bisnis ini harus mampu mempertahankan para konsumennya salah satu variabel yang dapat mempertahankan konsumen adalah kepuasan konsumen, setiap pelaku bisnis harus mampu membuat para konsumen selalu merasa puas dengan produk-produk mereka, baik pada produk jasa atau pada produk barang.

Hal tersebut mendorong setiap pelaku bisnis menghadirkan kualitas pelayanan dan kualitas produk mereka menjadi lebih baik agar dapat menarik konsumen dengan sebanyak-banyaknya ini adalah salah satu cara memperbaiki manajemen pemasaran pada suatu perusahaan, manajemen pemasaran pada suatu perusahaan mempengaruhi kelangsungan produk atau jasa suatu perusahaan untuk mencapai laba perusahaan.

Menurut Kotler dalam Prof. Dr. Dra. Tatik Suryani, (2017:2) pada buku yang berjudul Manajemen Pemasaran Strategik Bank di Era Global bahwa manajemen pemasaran adalah suatu proses sosial dan manajerial dimana individu dan kelompok memperoleh apa yang mereka butuhkan melalui penciptaan atau pertukaran produk dan nilai dengan pihak lain. Teori tersebut menegaskan bahwa manajemen pemasaran berperan penting untuk mendapatkan konsumen, karena semakin baik manajemen pemasarannya semakin banyak pula orang yang akan membeli dan memakai produk atau jasa yang ditawarkan, beberapa upaya untuk memperbaiki manajemen pemasaran adalah meningkatkan kualitas pelayanan dan juga meningkatkan kualitas produk untuk mencapai kepuasan konsumen.

Hal inilah yang sedang diupayakan oleh ibu Sumarmi, memiliki usaha sejak 8 tahun terakhir tidak lantas selalu membuat konsumennya merasa puas dengan kualitas pelayanan dan kualitas produk jamu ibu Sumarmi, masih ada beberapa konsumennya yang mengeluhkan kualitas pelayanan dan juga kualitas produk jamu ibu Sumarmi, sehingga ada beberapa konsumennya yang beralih kepada produk pesaing.

Berdasarkan latar belakang diatas maka penulis merasa perlu untuk membuat suatu penelitian dengan judul "Pengaruh Kualitas Pelayanan dan Kualitas Produk Terhadap Kepuasan Konsumen Pada Usaha Mandiri (Jamu Keliling) Milik Ibu Sumarmi Tegalrotan Ciputat Tangerang Selatan" untuk membantu mengkaji lebih dalam tentang pengaruh kualitas pelayanan dan kualitas produk terhadap kepuasan konsumen agar nantinya ibu Sumarmi dapat meningkatkan kualitas pelayanan dan kualitas produk jamu keliling milik ibu 
Sumarmi untuk mencapai kepuasan konsumennya secara menyeluruh. Penelitian ini akan berfokus pada masalah kualitas pelayanan dan kualitas produk untuk produk sendiri penulis berfokus pada produk: Jahe, Beras kencur, Kunyit asam, Kunyit putih dan Temulawak, karena kelima produk tersebut adalah produk yang mendapat keluhan terbanyak dari konsumen dibandingkan produk lainnya.

\section{Rumusan Masalah}

Sejalan dengan permasalahan di atas, maka dapat

$$
\text { diajukan rumusan masalah }
$$

penelitian sebagai berikut:

1. Bagaimana Kualitas Pelayanan berpengaruh terhadap Kepuasan Konsumen pada Usaha Mandiri (Jamu Keliling) Milik Ibu Sumarmi?.

2. Bagaimana Kualitas Produk berpengaruh terhadap Kepuasan Konsumen pada Usaha Mandiri (Jamu Keliling) Milik Ibu Sumarmi?.

3. Bagaimana Kualitas Pelayanan dan Kualitas Produk secara bersama-sama berpengaruh terhadap Kepuasan Konsumen pada Usaha Mandiri (Jamu Keliling) Milik Ibu Sumarmi?

\section{Tujuan Penelitian} adalah :

Adapun tujuan dari penelitian ini

1. Untuk mengetahui bagaimana pengaruh Kualitas Pelayanan terhadap Kepuasan

Konsumen pada Usaha Mandiri (Jamu Keliling) Milik Ibu Sumarmi.

2. Untuk mengetahui bagaimana pengaruh Kualitas Produk terhadap Kepuasan Konsumen pada Usaha Mandiri (Jamu Keliling) Milik Ibu Sumarmi.

3. Untuk mengetahui bagaimana pengaruh Kualitas Pelayanan dan Kualitas Produk secara bersama-sama terhadap Kepuasan Konsumen pada Usaha Mandiri (Jamu Keliling) Milik Ibu Sumarmi.

\section{Manfaat Penelitian}

Hasil penelitian ini diharapkan dapat memberi manfaat sebagai berikut:

1. Bagi Peneliti

Dalam penelitian ini merupakan kelanjutan dari proses belajar mengajar dalam rangka berusaha menerapkan ilmu yang diperoleh penulis selama mengikuti pembelajaran berupa sistem perkuliahan dengan keadaan di lapangan, sehingga penulis mengharapkan penelitian ini menjadi pengalaman praktis dan dapat mengetahui seberapa besar kemampuan teoritis tersebut mampu diterapkan dalam kegiatan sehari-hari.

2. Bagi Universitas Pamulang

Dengan terlaksananya penelitian ini diharapkan dapat memberikan informasi dan sekaligus sebagai pedoman bagi pengembangan ilmu pengetahuan khususnya ilmu manajemen pemasaran pada Universitas Pamulang.

3. Bagi usaha Mandiri (Jamu Keliling) Milik Ibu Sumarmi.

Secara Praktis, hasil dari penelitian ini di harapkan dapat menjadi masukan yang bermanfaat bagi Usaha Mandiri (Jamu Keliling) Milik Ibu Sumarmi dan menjadi tolak ukur pemilik usaha dalam memberikan pelayanan dan kualitas produk yang terbaik sehingga dapat mencapai kepuasan konsumen secara menyeluruh yang akan berpengaruh pada kesetiaan konsumen.

\section{TINJAUAN PUSTAKA}

\section{Kualitas Pelayanan}

Kualitas Pelayanan adalah suatu keunggulan kualitas yang dimiliki oleh suatu layanan yang hanya dapat dinilai oleh konsumen, kualitas pelayanan merupakan salah satu elemen penting yang menjadi pertimbangan konsumen dalam melakukan pembelian sebuah produk barang atau jasa.

Indikator kualitas pelayanan:

a. Keandalan (Reliability),

b. Daya tanggap (Responsiveness) 
c. Kepastian /jaminan (Assurance),

d. Empati (Empathy),

e. Bukti nyata (Tangibles).

\section{Pengertian Kualitas Produk}

Kesimpulan Kualitas Produk adalah aspek ciri karakteristik untuk melihat kualitas sebuah produk.

Indiktor kualitas produk:

a. Kinerja (Performance),

b. Fitur (Features),

c. Reliabilitas (reliability),

d. Kesesuaian dengan spesifikasi (conformance of specifications),

e. Daya tahan (durability),

f. Estetika,

\section{Pengertian Kepuasan Konsumen}

Kesimpulan Kepuasan Konsumen merupakan suatu perasaan atau penilaian emosional dari konsumen atas penggunaan produk barang atau jasa ketika harapan dan kebutuhan terpenuhi dengan kata lain, jika pelanggan merasa apa yang diperoleh lebih rendah dari yang diharapkan maka konsumen tersebut tidak puas.

Indikator kepuasan konsumen:

a. Kesesuaian dengan harapan

b. Minat berkunjung/ membeli kembali.

c. Kesediaan merekomendasikan.

\section{METODEOLOGI PENELITIAN}

Jenis penelitian ini adalah kuantitatif dengan sifat penelitian deskriptif-asosiatif kausal. Penelitian ini dilakukan pada usaha jamu milik ibu Sumarmi dimana beliau berjualan keliling di daerah Tegalrotan, Kampung Sawah Baru, Ciputat, Tangerang Selatan, Banten. Waktu penelitian dimulai pada bulan Maret 2021. Populasi dalam penelitian ini adalah jumlah konsumen selama 3 tahun yaitu, dari tahun 2018 sampai 2020. maka didapatkanlah hasil jumlah konsumen sebesar 30.021 konsumen selama 3 tahun tersebut. Teknik pengambilan sampel dalam penelitian ini menggunakan tehnik Accidental Sampling yakni teknik pengambilan anggota sampel dengan berdasarkan kebetulan. Adapun jumlah sampel yang diperoleh dengan menggunakan rumus Slovin menggunakan tingkat error sebesar 10\% $(0,1)$ dan didapatkan sampel sebanyak 100 orang. Data yang diperoleh oleh kuesioner dengan jumlah sampel sebanyak 100 orang. Pengujian data kuesioner dianalisis dengan menggunakan perhitungan SPSS versi 26, pada uji regresi linear sederhana dan berganda, uji koefesien korelasi, koefesien determinasi dan uji hipotesis.

\section{HASIL PENELITIAN DAN PEMBAHASAN}
1) Pengaruh Kualitas Pelayanan Terhadap Kepuasan Konsumen (H1).

Berdasarkan hasil penelitian bahwa kualitas pelayanan terbukti berpengaruh terhadap kepuasan konsumen, hal ini dibuktikan dengan nilai thitung $>$ ttabel $(7,746>1,984)$ dan nilai signifikansi sebesar $(0,000<0,05)$. Hasil penelitian ini menguatkan hasil penelitian terdahulu yang dilakukan oleh Annisa Maulidah (2019), Didukung oleh penelitian Aji Kurniawan, I Gde Made Metera, Ni Ketut Adi Mekarsari, September (2018), Selanjutnya didukung oleh penelitian Ni Made Arie Sulistyawati dan Ni Ketut Seminari (2015), Serta didukung oleh penelitian Tri Hari Koestanto (2014), yang menyatakan bahwa kualitas pelayanan berpengaruh terhadap kepuasan konsumen dalam hal ini adalah indikator kualitas pelayanan yang meliputi,

keandalan/reliability,ketanggapan/resp onsiveness,

kepanstian/jaminan/assurance, empati/empathy dan bukti nyata/tangibles. Artinya semakin baik kualitas pelayanan yang diberikan maka konsumen akan merasa semakin puas.

2) Pengaruh Kualitas Produk Terhadap Kepuasan Konsumen (H2).

, Kesesuaian/Confermance, Daya Tahan/durability dan Estetika. Artinya Bahwa kualitas produk berpengaruh terhadap kepuasan konsumen hal ini dibuktikan dengan nilai thitung $>$ ttabel 
$(9,391>1,984)$ dan nilai signifikansi sebesar $(0,000<0,05)$. Hasil penelitian ini menguatkan hasil penelitian terdahulu yang dilakukan oleh Freekly Stefly Maramis, Jantje Sepang, \& Agus Supandi Soegoto, Juli (2018), didukung oleh penelitian Tias Windarti \& Mariaty Ibrahim, Oktober (2017), serta didukung oleh penelitian Meida Ramita Sari \& Rahayu Lestari, Januari (2019), yang menyatakan bahwa kualitas produk berpengaruh terhadap kepuasan konsumen dalam hal ini adalah indikator kualitas produk yang meliputi, Kinerja/Performa, Fitur/Fitures,

Keandalan/Reabilitysemakin baik kualitas produk yang diberikan maka konsumen akan merasa semakin puas.

3) Pengaruh Kualitas Pelayanan dan kualitas produk Terhadap Kepuasan Konsumen (H3).

Terakhir bahwa kualitas pelayanan dan kualitas produk secara bersama-sama (simulitan) berpengaruh terhadap kualitas konsumen, hal ini dibuktikan dengan nilai Fhitung > Ftabel $(46,273>3,090)$ nilai signifikansi $(0,000<0,05)$. Hasil penelitian ini menguatkan hasil penelitian terdahulu yang dilakukan oleh Biily (2019), Didukung oleh penelitian Basrah Saidani \& Samsul Arifin (2012), Serta didukung oleh penelitian Diapinsa Gema Zakaria, Desember (2018), menyatakan bahwa kualitas pelayanan dan kualitas produk secara bersamasama berpengaruh terhadap kepuasan konsumen dalam hal ini adalah indikator kepuasan konsumen yang meliputi, kesuaian harapan, minat berkunjung/membeli kembali, dan kesediaan merekomendasikan. Artinya semakin baik kualitas pelayanan dan kualitas produk secara bersama-sama yang diberikan maka konsumen akan merasa semakin puas.

\section{KESIMPULAN DAN SARAN Kesimpulan}

Berdasarkan hasil penelitian pada pembahasan Bab IV mengenai kualitas pelayanan dan kualitas produk terhadap kepuasan konsumen pada usaha mandiri (jamu keliling) milik Ibu Sumarmi Tegalrotan Ciputat Tangerang Selatan, maka penulis menarik kesimpulan dan memberikan beberapa saran sebagai masukan bagi usaha mandiri (jamu keliling) milik ibu Sumarmi, sebagai berikut :

1. Kualitas Pelayanan terbukti berpengaruh secara parsial dan signifikan terhadap kepuasan konsumen.

Dari hasil koefisen korelasi diperoleh nilai sebesar 0,616 , dari hasil uji hipotesis $t$, bahwa thitung 7,746 > ttabel 1,984, dengan nilai Probability signifikansi sebesar 0,000 $<0,05$, dari hasil uji determinasi $\mathrm{r}^{2}$ diperoleh nilai 0,380, jadi dari variabel kualitas pelayanan mampu menjelaskan sebesar 38,0\% terhadap kepuasan konsumen.

2. Kualitas Produk terbukti berpengaruh secara parsial dan signifikan terhadap kepuasan konsumen.

Dari hasil koefisen korelasi diperoleh nilai sebesar $\mathrm{m} 0,688$, dari hasil uji hipotesis $t$, bahwa thitung 9,391 > $t$ tabel 1,984, dengan nilai Probability signifikansi sebesar 0,000 $<0,05$, dari hasil uji determinasi $\mathrm{r}^{2}$ diperoleh nilai 0,474, jadi dari variabel kualitas pelayanan mampu menjelaskan sebesar $47,4 \%$ terhadap kepuasan konsumen.

3. Kualitas Pelayanan dan Kualitas Produk secara bersama-sama terbukti berpengaruh pada kepuasan konsumen.

Dari hasil koefesien korelasi secara simultan diperoleh nilai sebesar 0,699, dari hasil uji hipotesis $\mathrm{F}$ bahwa Fhitung 46, $273>$ Ftabel 3.090 dengan nilai probability signifikansi sebesar $0,000<0,05$, dari hasil uji determinasi $\mathrm{r}^{2}$ diperoleh nilai 0,488 , jadi dari variabel kualitas pelayanan dan kualitas produk mampu menjelaskan sebesar 48,8\% terhadap kepuasan konsumen. 
Saran

\section{Berdasarkan hasil responden kualitas pelayanan terhadap kepuasan konsumen.}

Perlu adanya perbaikan pada indikator ketanggapan/responsiveness, empati/empathy, dan bukti nyata/tangibles, karena masih terdapat konsumen yang tidak setuju dengan pernyataan yang diberikan mengenai indikator tersebut dalam kuesioner. Dalam hal ini kualitas pelayanan sangat berpengaruh terhadap kepuasan konsumen pada usaha mandiri (jamu keliling) milik Ibu Sumarmi Tegalrotan Ciputat Tangerang Selatan. Dimana kualitas pelayanan harus memberikan tanggapan yang dapat memenuhi keinginan konsumen, serta memberikan wujud dalam penampilan sehingga menjadikan konsumen lebih merasa puas dengan kualitas pelayanan yang diberikan. setuju dengan pernyataan yang diberikan mengenai indikator tersebut dalam kuesioner. Dalam hal ini kualitas produk sangat berpengaruh terhadap kepuasan konsumen pada usaha mandiri (jamu keliling) milik Ibu Sumarmi Tegalrotan Ciputat Tangerang Selatan. Dimana kualitas produk harus memiliki kesan yang baik kepada konsumen sehingga memenuhi harapan konsumen. Dalam hal kualitas produk diharapkan agar ibu Sumarmi mampu untuk menambah wawasan mengenai obat-obatan herbal agar kedepannya dapat lebih tepat lagi dalam menangani keluhan-keluhan konsumen serta diharapkan kedepannya mampu menambah varian produk supaya tetap terus bertahan atau bahkan berkembang dan mampu bersaing dengan produk jamu lainnya.

2. Berdasarkan hasil responden kualitas pelayanan terhadap kepuasan konsumen.

perlu adanya manajemen waktu dan manajemen operasional yang lebih baik lagi sehingga dapat memperlancar jalannya usaha kemudian diharapkan kedepannya pemasaran produk dapat secara online contoh pemasaran melalui media sosial seperti whatsapp dan instagram hal ini dapat mempermudah konsumen menjangkau produk.

3. Peneliti menyarankan agar peneliti selanjutnya dapat menambah variabelvariabel bebas lainnya diluar penelitian ini agar dapat mengetahui variabelvariabel apa saja yang dapat mempengaruhi kepuasan konsumen.

\section{DAFTAR PUSTAKA}

Almahdi, A. (2020). Rumah Coklat. Bogor. Intelegensia Media.

Astuti, M, S,Si., M.M. (2020).Keunggulan Kompetitif UMKM Naik Kelas. Yogyakarta. Deepublish.

Astuti, M, S,Si., M.M. (2020). Manajemen Pemasaran. Yogyakarta. Deepublish.

Candrianto, ST. M.Pd. (2021). Kepuasan Pelanggan Suatu Pengantar. Malang. Literasi Nusantara.

Djunaidi, F,G, SE., M.Si. (2020). Analisis Faktor-Faktor yang Mempengaruhi Kepuasan Konsumen dalam Menggunakan Minyak Kayu Putih Pada Ketel Walbarua Ubung. Surabaya. Qiara Media.

Duli, N. (2019). Metodologi Penelitian Kuantitatif Beberapa Konsep Dasar Untuk Penulisan Skripsi \& Analisis Data Dengan SPSS. Yogyakarta. Deepublish.

Firmansyah, M. A. (2019). Manajemen. Surabaya. Qiara Media.

Firmansyah, M. A. (2019). Pemasaran Peoduk dan Merek. Surabaya. Qiara Media.

Handayani, T, Fathoni, M, A. (2019). Buku Ajar Manajemen Pemasaran Islam. Yogyakarta. Deepublish.

Hendrataka, K, Suyatna Yasa, P, N, S.E., M. Si, Indiani, N, L, P, S.E., M.M. (2021). Sistem Informasi Pemasaran Pada Masa Covid 19 Pada Industri Otomotif. Surabaya. Scopindo Media Pustaka.

Hermawan, I, S.Ag.,M.Pd.I. (2019). Metodologi Penelitian Pendidikan (Kualitatif, Kuantitatif dan Mixed Method). Semarang. Hidayatul Quran. 
Mursid, M, C, Suliyanto \& Rahab. (2019). Menanamkan Nilai Inovasi Berbasis Syariah Untuk Meningkatkan Kinerja Pemasaran Produk Baru di Industri Keuangan Mikro Syariah. Banjarbaru Kalimatan Selatan. Khoirunnisa.

Mutiawati, C, dkk. (2019). Kinerja Pelayanan Angkutan Umum Jalan Raya. Yogyakarta. Deepublish.

Nurdin, I, M.Si. dkk. (2019). Metodeologi Penelitian Sosial. Surabaya. Media
Sahabat. Cendika.

Purba, E, dkk, (2021). Metode Penelitian Ekonomi. Medan. Yayasan Kita Penulis.

Rahma, E. (2018), Akses dan Layanan Perpustakaan. Jakarta. Kecana.

Rinaldi, A, S.Si, M.Si. dkk. (2021). Statistika Inferensial untuk Ilmu Sosial dan Pendidikan. Bogor. IPB Press.

Tjiptono, F \& Diana, A (2020). Pemasaran. Yogyakarta. Andi Publisher. 